This item was submitted to Loughborough's Research Repository by the author.

Items in Figshare are protected by copyright, with all rights reserved, unless otherwise indicated.

\title{
Metabolic rate and clothing insulation data of children and adolescents during various school activities
}

PLEASE CITE THE PUBLISHED VERSION

PUBLISHER

(C) Taylor \& Francis

LICENCE

CC BY-NC-ND 4.0

REPOSITORY RECORD

Havenith, George. 2019. "Metabolic Rate and Clothing Insulation Data of Children and Adolescents During Various School Activities". figshare. https://hdl.handle.net/2134/3059. 
This item was submitted to Loughborough's Institutional Repository by the author and is made available under the following Creative Commons Licence conditions.

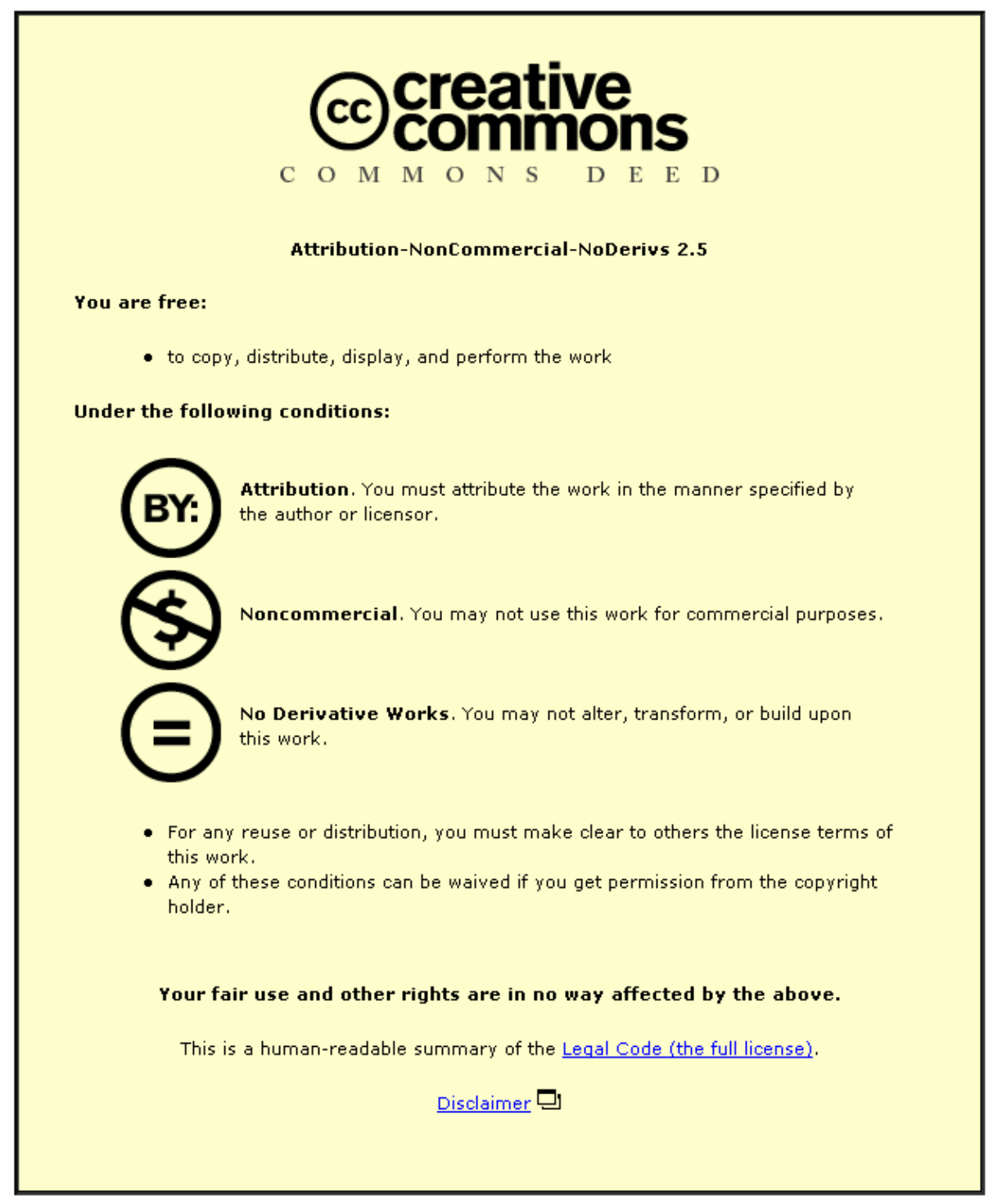

For the full text of this licence, please go to: http://creativecommons.org/licenses/by-nc-nd/2.5/ 
Metabolic rate and clothing insulation data of children and adolescents during various school activities

George Havenith ${ }^{1,2}$

${ }^{1}$ TNO Human Factors, Soesterberg, 3769 ZG, NL

${ }^{2}$ Loughborough University, Dept. Human Sciences, Loughborough, LE11 3TU, UK

\section{June 2007 FINAL ACCEPTED VERSION}

Address for correspondence:

Dr. G. Havenith

Dept. Human Sciences

Loughborough University

Loughborough

LE11 3TU

Phone: +44 1509223031

Fax: +44 1509223940

Email: g.Havenith@lboro.ac.uk

Keywords: energy expenditure, metabolism, children, oxygen uptake, school, clothing insulation, climate assessment 


\begin{abstract}
Data on metabolic rates $(\mathrm{n}=81)$ and clothing insulation $(\mathrm{n}=96)$ of school children and adolescents (A, primary school: age 9-10; B, primary school: age 10-11 year; C, junior vocational (technical) education: age 13-16 (lower level); D, same as C but at advanced level; and E, senior vocational (technical) education, advanced level: age 16-18) were collected (Diaferometer, Oxylog, Heart Rate derivation) during theory-, practical- and physical education- lessons. Clothing insulation was calculated from clothing weight, covered body surface area, and the number of clothing layers worn. Clothing insulation was found to be similar to that expected for adults in the same (winter) season, with minimal variation with age or school type (0.9 to 1.0 clo; 1.38 clo where coverall was worn), but more variation within groups (coefficient of variation 6-12\%). Metabolic rate values $\left(\mathrm{W} . \mathrm{m}^{-2}\right)$ were lower than expected from adult data for similar activities, but are supported by other child data. The results of this study can be used to establish design criteria for school climate control systems or as general data on energy expenditure for children and adolescents. The results emphasise the need for specific child data and shows the limited value of size-corrected adult data for use in children.
\end{abstract}

\title{
1. Introduction
}

In the evaluation of thermal comfort in buildings and in the specification of design guidelines for heating and air conditioning systems for occupied spaces, extensive use is made of the calculation of the human heat balance in relation to subjective thermal comfort votes. This relation was formalised by Fanger (1970) and later transformed into an international standard (ISO 7730 2005). The thermal comfort sensation of building occupants is determined by the climatic parameters (room temperature, humidity, air speed and radiation levels) and by personal factors such as the activity and clothing level of the occupants (Havenith et al. 2002). The motivation for the present study was to collect data needed for the determination of design specifications of school buildings. In this application, climatic requirements for 
thermal comfort are deduced from clothing insulation and activity levels of the building occupants, using ISO 7730 (2005). Other applications for such data can be found in the areas of child nutrition (Torun 1989). Hence, this is not a hypothesis driven study, but a data gathering study.

Clothing insulation in pupils will vary depending on the season and on the lesson type. The latter will be the case when special clothing is worn. Examples are the use of Physical Education (PE) uniforms (sports clothing) in Physical Education lessons, lab coats in Chemistry and coveralls in Woodworking lessons. A full analysis of the clothing insulation in pupils would therefore require a year round survey and a survey for different lesson types. The former would be very time consuming and it is considered that the variation in time can be easily captured based on observations of clothing worn and by relating these observations to existing data (ISO 9920 2003). For the present paper it was considered relevant to look at variations in clothing insulation within a group of pupils and to look at the effect of specialised clothing.

For use in the heat balance equation, activity levels are expressed as metabolic rates, i.e. heat production in Watt or in Watt per square metre body surface area. A large amount of data on metabolic rates for various activities is available, and can be deduced from tables (ISO 8996 2004, Spitzer et al. 1982, Ainsworth et al. 1993). However these contain few 'education related' activities and what is available is almost exclusively for adults. Conversion of adult data to children e.g. based on body weight or surface area (Bouchard et al. 1983), can lead to substantial errors (Torun 1983). Alternatively an age related correction may be used (Torun 1989) or the FAO/WHO/UNU (WHO 1985) correction that is a sex specific basic metabolic rate multiplier. However all these corrections will inevitably lead to errors as they do not consider all relevant factors (weight, surface area etc). Hence there is a need to collect actual data for a variety of school activities. 
In schools activity levels will vary with different lessons, and activity levels are often associated with the type of classroom. In the Netherlands three relevant classroom types were identified for this study in discussions with the ministry of education: 1 . Theory rooms, for educational styles where no special learning or teaching materials are required 2. Practical rooms, which are specifically designed for practical lessons (Physical Education, Arts, Vocational skills etc) and 3. Combined theory-practical rooms, which are designed to allow use for both practical and theory lessons.

\section{Methods}

\subsection{Schools, lessons and pupils}

In order to obtain data relevant to schools, a number of different schools were approached and after consent of school management, teachers, parents and pupils metabolic rates were determined in the pupils during various lessons and clothing insulation was determined. Measurements were performed in five groups of pupils (total 96 for clothing, 81 for metabolic rate):

A. Primary school, level 6, age 9-10 year;

B. Primary school, level 7, age 10-11 year;

C. Junior vocational (technical) education (junior high school) age 13-16;

C* Same as C, but including protective coveralls for clothing insulation determination

D. Junior vocational education, advanced level (junior high school) age 13-16;

E. Senior vocational (technical) education, advanced level (senior high school) age 16-18.

The lessons that were studied for metabolic rate are listed in Table 1. 


\subsection{Activity level / metabolic rate}

Several methods are available for determination of metabolic rate (for detailed description see ISO 8996 2004, Scrimshaw et al. 1996, Norgan 1996 and Müller and Bosy-Westphal 2003). The most accurate method for short (hour) activity periods is the measurement of metabolic gas exchange (Oxygen uptake, [ $\left.\&_{\mathrm{O}_{2}}\right]$ and carbon dioxide production $\left[\& \mathrm{CO}_{2}\right]$ ), followed in reliability by analyses of heart rate and finally various estimation methods using posture and movement analysis or simply looking up similar activities in tables (Havenith et al. 2002). The latter two, the table method and the estimation of metabolic rate based on posture and movement analyses (ISO 8996 2004) were considered not applicable, as these have not been validated in children.

The most accurate method, respiratory gas analysis, requires gas analyses equipment to be connected to the pupil during the activity. In some lessons this would interfere unacceptably with the freedom of movement. For this reason a variety of methods were applied (one per case).

\subsubsection{Oxylog}

The preferred equipment available in terms of a balance of freedom of movement and accuracy was a portable oxygen analyser (P.K.Morgan, Chatham, Kent) mounted on a small backpack frame with a data logger (total $4.5 \mathrm{~kg}$ ). It was used for measurements where the pupil would move around in the classroom. It could also be used in a static situation, by putting it next to the pupil on a table or chair, so that the weight was not carried. Absolute precision for calculation of metabolic rate with this system is better than $5 \%$ (Louhevaara et al. 1985; Harrison et al. 1982). The system was calibrated with certified gas mixtures and a volume syringe. Some problems exist with this measurement system: 1-at low activity levels (especially in children) the respiratory flows are too low for proper function of the turbine 
flow meter; 2-in fast moves the inertia of the back pack will affect the activity; 3-the weight of the system will affect the metabolic rate significantly if it exceeds $10 \%$ of body weight (Hong et al. 2000).

\subsubsection{Diaferometer}

Given the problems with low respiratory flows at low activity levels, typically occurring in theory lessons in young children, a system was devised using a Diaferometer (Kipp \& Zonen, Delft) gas analyser. This open circuit indirect calorimeter is normally used for accurate determinations of resting metabolic rates by analysing the gas contents of a fixed air volume it draws from the participant (Torun and Viteri 1981). In resting metabolism applications air is typically drawn from a hood that covers the persons head. In the present experiment, the system was connected by tubing to five individual children-size face masks simultaneously, and had a shunt to the room. The slight negative pressure produced in the face masks reduced the problems of leakage on expiration as well as effects of the valve system resistance. The expired air of the five pupils was mixed in the system and analysed. Metabolic rate was calculated using Weir's equation (Weir 1949), producing an average metabolic rate value for the five pupils. This system was only used in static classroom situations.

\subsubsection{Heart rate analysis}

Heart rate measurement for determination of metabolic rate is the most commonly employed method in children (Müller and Bosy-Westphal 2003). This method was shown to produce reliable results (within 10\% of respiratory gas analysis value; Havenith 1987), but is limited to dynamic exercise as static work changes the heart rate-metabolic rate relationship (Bouchard and Trudeau 2007). For the present experiment it was used in those situations where fast movements were present (PE lessons), as an indirect measurement of metabolic rate. Heart rates (Polar Electro, Finland) were obtained during the lessons and these were later converted to metabolic rates using a calibration curve of heart rate versus metabolic rate that was 
obtained from each individual participant on a cycle ergometer. Pupils were allowed to get used to the equipment until they felt comfortable with it, before the measurement started. Metabolic rate measurements lasted 45 minutes to 1 hour.

\subsection{Clothing insulation}

Measurement of clothing insulation (ISO 9920 2003) was not practical, given high costs involved and the lack of thermal manikins of correct size. As alternative method, estimation of insulation values was considered. Using existing tables of insulation (ISO 9920 2003) was not considered valid, as these were all for adult sizes. Estimations using regression equations (McCullough et al. 1984) were also based on adult clothing, but as these were using physical measurements of the clothing ensembles it was decided that these could be adapted to use in children by scaling of the measurements. The equation used for the calculation of intrinsic insulation is:

$$
I_{\mathrm{cl}}=0.919+0.255 \cdot \text { weight }-0.00874 \cdot B S A_{0}-0.0051 \cdot B S A C_{1}
$$

with :

$I_{\mathrm{cl}}=$ intrinsic clothing insulation (clo)

weight $=$ clothing weight $(\mathrm{kg})$ excluding shoes

$B S A_{0}=$ body surface area nude (\%)

$B S A C_{1}=$ body surface area covered by one layer of clothing (\%)

This equation calculates clothing insulation by assuming an insulation based on the weight for multi layer clothing and then subtracting insulation for nude and single layer areas. The surface areas are automatically scaled. It was decided to scale the clothing weight based on body surface area ( $A_{D}$, Dubois and Dubois 1916), taking a $1.8 \mathrm{~m}^{2}$ person as reference. Garment weights were determined during PE lessons when pupils had changed into PE-kit. 
After the PE-lesson, the clothed pupils were photographed front and back, and these were used to analyse the size of uncovered and covered surface areas.

Summary statistics of the data were produced using SYSTAT (SYSTAT Inc 2004).

\section{Results}

The physical data on the participant groups and the results of the clothing measurements are presented in Table 2. The data measured related to metabolic rate are presented in Table 3. The three methods worked without complications in the different situations. The Diaferometer measurements took a short while for the participants to get used to (face mask), visible by an initial hyperventilation. However, after about 20 minutes data stabilised and respiratory exchange ratios returned to normal (Jones and Campbell 1982). With the Oxylog measurements problems can occur related to low respiratory minute volumes which affect flowmeter response. These problems were not observed at the high schools, while these problems were present when used at primary school level for static situations due to the low ventilatory volume of the young children. In such cases the data were excluded. In the Physical Education lessons, the Oxylog could not be applied due to its impact on the activity (physical size and weight) as well as for safety towards the wearer and other pupils. The calibrations for the Heart Rate method on the cycle ergometer functioned without problems and heart rates observed in the activities were high enough for the activity to be classified as dynamic exercise; a requirement for application of this method (Åstrand and Rodahl 1986). Clothing insulations were not significantly different between groups, except for group C* where the higher insulation was caused by the additional coverall. 


\section{Discussion}

This study was a data gathering exercise with the main purpose of producing tabulated data on metabolic rates in school children in various lesson types. Such tabulated data exist for adults involved in a multitude of activities (Spitzer et al. 1982; ISO 8996 2004), but few were available for children and none for school activities. The adult data have been used for many years in climatic stress and thermal comfort assessments of workplaces and buildings (Havenith et al. 2002, Havenith 2004) and in the design phase of climate control systems. The metabolic rate is one of the six parameters needed as input into such calculations (the others being: air temperature, radiant temperature, relative humidity or water vapour pressure, air speed, and clothing insulation; Havenith 2004). Using the data produced in this study, rather than estimating data for children based on adult data, this work can now be expanded with improved validity to school environments.

A second area of application of metabolic rate tables is that of child nutrition. Children data were collected and published by various authors (e.g. Bandini et al. 2006, Spadano et al. 2003, 2005, Torun, 1989) and are used to calculate daily energy and nutritional requirements. Again, no school related data were available so far and these are provided in this study.

A second goal of the study was to provide more insight in the clothing 'behaviour' of the school children. For a full assessment a year round collection of data would be required, which would have been beyond the scope of this study. In addition, due to fashion changes, data might 'age' quickly. Nevertheless, it was deemed relevant to study clothing insulation even if it was just a snapshot in time. Data were gathered to look at variation of insulation within and between groups. So, even if absolute values may change over years, it was expected that the information on variation would remain valid. 


\subsection{Clothing Insulation}

Results in Table 2 show that though a reasonable amount of variation is present within each group ( $\mathrm{CV}=6-12 \%)$, the average insulation value is quite similar between groups (A to $\mathrm{E}$, excl. C*; within $6 \%$ of overall mean). This can be explained by the high level of uniformity in the clothing worn. Though no school uniform exists in the Netherlands, the typical clothing is comprised of jeans, polo shirt or blouse, and sweater. These have similar covered body areas and will thus provide similar insulation, modulated by the clothing weight.

Wearing of special protective clothing (e.g. welder apron in relevant lessons) was avoided by pupils where possible. Only the coverall was worn systematically in practical lessons (woodworking, welding). In one school, about one third of pupils in several classes wore coats in the classroom. This appeared to have started as a protection against theft, but though measures were in force solving this problem the habit continued. As the functional need for wearing coats had disappeared, this habit may now be regarded as ‘fashion'. For this reason, no coats were included in the clothing data collected. Absolute clothing insulation values range around 0.9 to 1 clo, which would be regarded as normal for office conditions in wintertime (ISO 7730 2005). As mentioned in the introduction, these data only provide a snapshot of the real values, but they do provide data on variation at a time when expected inter-individual variation is highest (winter). Absolute insulation values seem to be in line with values expected for adults in this time of year (ISO 7730 2005; ISO 9920 2003).

\subsection{Metabolic rate}

All three measurement methods (Diaferometer, Oxylog, and Heart Rate) were deemed appropriate for the specific application situations (ISO 8996 2004, Scrimshaw et al. 1996, Norgan 1996). Alternative methods were either not fit for the short periods investigated (doubly labelled water) or too inaccurate lacking proper reference data (observation analysis, 
actimeters). The observed values (Table 3) for theory rooms ranged from 52 to $88 \mathrm{~W} . \mathrm{m}^{-2}$. This includes one outlier, which was of an extremely nervous, fidgeting pupil (E-business administration). As this is considered exceptional this person was omitted from the dataset. The range then becomes $52-72 \mathrm{~W} \cdot \mathrm{m}^{-2}$.

For the combined theory-practical rooms, similar ranges are observed, but at a higher absolute value (69-80 W.m ${ }^{-2}$. This is clearly related to the different (higher) activity patterns in these rooms, where the students have more freedom to move around. For the practical rooms, the variation within lessons (between pupils in the same lesson) and between different lessons are both quite large. Between-lesson variation is directly related to content of the different lessons, affecting the average activity level of the group. The spread within a group in a single lesson on the other hand is representing the wider choice of the individual students to vary their activity/mobility levels within the same task. Typical range is between 59 and $121 \mathrm{~W} \cdot \mathrm{m}^{-2}$ (excluding PE).

Values have been normalised (adjusted) by body surface area. Given the use in heat balance models for determination of thermal comfort, this is relevant to the application as input units for this are typically in W.m ${ }^{-2}$. For calculation of surface area the Dubois and Dubois (1916) equation was used. It may be questioned whether this is valid for the current young groups. To study this, the surface area was also calculated using the theoretical model postulated by Wang and Hihara (2003). It was observed that this stayed within 1.5\% of the Dubois and Dubois value. In comparison to other equations, including children's, Wang's equation stays within $2.5 \%$ for surface areas above $1 \mathrm{~m}^{2}$. Given these low deviations, it was preferred to work with a single equation rather than having separate ones for different age groups. In biology, standardisation or normalisation of data is typically performed based on body weight $\left(\mathrm{W} \cdot \mathrm{kg}^{-1}\right)$ and therefore this was also presented in Table 3. 
Use of these types of scaling suggests that it may be possible to use adult data and convert them to the lower weight or surface area for young pupils. However substantial evidence exists that values from one age group should not be converted to other age groups using 'per unit of weight' data as the relation is not linear (Rogers et al. 1995). In addition, this nonlinear relation between body weight and metabolic rate varies with the type of activity (Rogers et al. 1995; Norgan 1996). It is also highly likely that this is also true for the 'per unit of surface area' values, as the ratio of body surface area per unit of (muscle) mass changes dramatically with age.

Comparison of observed values with data for adults provided in ISO 8996 (2004) shows that theory class data are substantially below those for the adult value of $100 \mathrm{~W} \cdot \mathrm{m}^{-2}$ for activity 'sitting quietly, light writing exercise'. The same is the case for combined theory-practical classes. For the practical classes, table values for adults for woodworking showed a range of 110 to $175 \mathrm{~W} \cdot \mathrm{m}^{-2}$. Measured individual values in the present study ranged from 70 to 140 W. $\mathrm{m}^{-2}$. This indicates that the school values are lower than would be expected from ISO 8996 (2004) data. In part this may be attributed to body size, giving lower values for children (they have a larger surface for their mass which could result in a lower metabolic rate per square meter). However for the older age groups (group D and E) body size is comparable to adults and values are still lower than those of ISO 8996 (2004). ISO 8996 data is very much based on workplace data however, which may result in a higher activity level than seen in the pupils.

For the measurements using the Diaferometer, it cannot be excluded that the equipment could have affected activity levels due to the constant connection of the facemask to a breathing tube which may have limited movement. However, according to teachers the activity levels observed were typical. 
For children, the majority of available data in literature is based on 24 hour or longer heart rate recordings or measurements using doubly labelled water. These total energy expenditure data are summarised by Scrimshaw et al. (1996) and are presented as 24 hour averages. The values are 74 to 80 watts (approx. 3.3 W. $\mathrm{kg}^{-1}$ ) for 6-8 year olds, 97 to 106 (approx. 2.45 W.kg${ }^{1}$ ) watts for 10-12 year olds and 133 to 140 watts (approx. $2.15 \mathrm{~W} \cdot \mathrm{kg}^{-1}$ ) for 14-16 year olds. This is substantially more than the resting metabolic rate (RMR; around 60 to $70 \%$ higher) and these averages are above the values observed in the theory lessons in the current study. The most likely explanation is a much higher energy expenditure during out of school hours that increases the average. The values observed in this experiment for theory lessons are higher than the RMR for the age group (Black et al. 1996).

Spadano et al. (2003) observed in 12 year old girls resting metabolic rates of $50 \mathrm{~W} \cdot \mathrm{m}^{-2}$ (1.56 $\mathrm{W} . \mathrm{kg}^{-1} ; 69.9$ watt $)$ and $68.8 \mathrm{~W} . \mathrm{m}^{-2}\left(2.12 \mathrm{~W} . \mathrm{kg}^{-1} ; 95.3\right.$ watt $)$ for sitting and $73.3 \mathrm{~W} . \mathrm{m}^{-2}(2.26$ W.kg ${ }^{-1}$; 101.6 watt) for standing in 12 year olds. This group falls between group B and C ageand size wise. Metabolic rates for the theory lessens of the current experiment are close to the sitting values observed by Spadano et al., especially when considering the 'per weight' value, with the 'per surface area' values being lower in group B. Rogers et al. (1995), studying resting and walking in pre and circumpubertal children observed RMR's of 59.7 W.m ${ }^{-2}$ for the prepubertal children (59.7 W, $2.07 \mathrm{~W} . \mathrm{kg}^{-1}, 28.8 \mathrm{~kg}$, 8y old) and $52.9 \mathrm{~W} . \mathrm{m}^{-2}$ for the circumpubertal children (78.8W, $1.53 \mathrm{~W} . \mathrm{kg}^{-1}, 12.8$ years old, $\left.51.5 \mathrm{~kg}\right)$.

The values for the present youngest group, which is a year older and has a higher weight than Roger et al.'s prepubertal group, seem a bit low when expressed as W.m ${ }^{-2}$ or W. $\mathrm{kg}^{-1}$, but in absolute terms the numbers seem right for the low activity level of theory lessons. For the current group C, slightly older than the circumpubertal children, values for the theory lessons are clearly higher than the RMR data from Rogers et al. 
In summary, data for clothing insulation and metabolic rate were obtained for pupils of different age and in different lessons. Clothing insulation was found to be similar to that expected for adults in the same (winter) season, with minimal variation with age but substantial variation within the groups. Metabolic rate values, obtained through three different methods, were lower than would be expected from adult data, but are supported by other child data. For design of climate control systems this implies that adults values for clothing insulation can be used in calculations for children, but also that specific children values for metabolic rate are required, as these were lower (per unit of mass or surface area) than adult values. Based on the data obtained a higher comfort temperature for the children compared to adults is expected based on the lower metabolic rates observed in the school children.

\section{Acknowledgement}

This work was supported by a grant of the Netherlands Ministry of Education. The author thanks

Mr. L. Wammes for his technical support and the late Dr. N.G. Norgan for his constructive comments on the manuscript.

\section{References}

ÅSTRAND, P.O. AND RODAHL, K., 1986, Textbook of work physiology, third edition, McGraw-Hill International Editions, Singapore.

AINSWORTH, B.E., HASKELL, W.L., LEON, A.S., JACOBS, D.R., MONTOYE, H.J., SALLIS, J.F. AND PAFFENBARGER, R.S., 1993, Compendium of physical activities: classification of energy costs of human physical activities. Medicine and Science in Sports and Exercise, 25, 71-80.

BANDINI, L.G., SPADANO-GASBARRO, J. AND MUST, A., 2006, Racial differences in the decline in resting metabolic rate (RMR) during the pubertal period in girls, FASEB Journal, 20, A587-A588 Part 1. 
BLACK, A.E., COWARD, W.A., COLE, T.J. AND PRENTICE, A.M., 1996, Human energy expenditure in affluent societies: an analysis of 574 doubly labelled water measurements. European Journal of Clinical Nutrition, 50, 72-92.

BOUCHARD, C., TREMBLAY, A., LEBLANC, C., LORTIE, G., SAVARD, R. AND THERIAULT, G., 1983, A method to assess energy expenditure in children and adults. American Journal of Clinical Nutrition 37, 461-467.

BOUCHARD, D.R. AND TRUDEAU, F., 2007, Reliability of the assessment of the oxygen/heart rate relationship during a workday, Applied Ergonomics 38, 491-497.

DUBOIS, D. AND DUBOIS, E.F., 1916, Clinical Calorimetry: A formula to estimate the appropriate surface area if height and weight be known, Archives of internal medicine, 17, 863-871.

FANGER, P.O., 1970, Thermal Comfort, McGraw Hill publ. New York.

HARRISON, M.H, BROWN, G.A. AND BELYAVIN, A.J., 1982, The Oxylog - An Evaluation, Ergonomics, 25, 809-820.

HAVENITH, G., 1987, Determination of clothing insulation and metabolic rate at the workplace (in Dutch), Report IZF 1987 C-16, TNO Institute for Perception, Soesterberg.

HAVENITH, G., 2004, Thermal Conditions Measurements, in: Handbook of Human Factors and Ergonomics Methods, Neville Stanton, Alan Hedge, Hal W. Hendrick, Eduardo Salas, Karel Brookhuis (Eds), Taylor and Francis.

HAVENITH, G., HOLMÉR, I. AND PARSONS, K., 2002, Personal factors in thermal comfort assessment: clothing properties and metabolic heat production, Energy and Buildings, 34, 581-591.

HONG, Y., LI, J.X. AND WONG, A.S.K, 2000, Effects of Load Carriage on Heart Rate, Blood Pressure and Energy Expenditure in Children, Ergonomics, 43, 717-727. 
ISO 7730, 2005, Ergonomics of the thermal environment. Analytical determination and interpretation of thermal comfort using calculation of the PMV and PPD indices and local thermal comfort criteria, International Standardisation Organisation, Geneva. ISO 8996, 2004, Ergonomics of the thermal environment. Determination of metabolic rate, International Standardisation Organisation, Geneva.

ISO 9920, 2003, Ergonomics of the thermal environment. Estimation of the thermal insulation and evaporative resistance of a clothing ensemble, International Standardisation Organisation, Geneva.

JONES, N.L. AND CAMPBELL, E.J.M., 1982, Clinical Exercise Testing, W.B. Saunders Company, Philadelphia.

LOUHEVAARA, V., ILMARINEN, J. AND OJA, P., 1985, Comparison of three field methods for measuring oxygen consumption, Ergonomics, 28 463-470.

MCCULLOUGH E.A., 1984, A comprehensive database for estimating clothing insulation; IER technical report 84-01, Kansas State University, Manhattan, Kansas 66506.

MÜLLER, M.J. AND BOSY-WESTPHAL, A., 2003, Assessment of Energy expenditure in children and adolescents, Current opinion in clinical nutrition and metabolic care, $\mathbf{6}$, 519-530.

NORGAN, N.G., 1996, Measurement and interpretation issues in laboratory and field studies of energy expenditure, American Journal Of Human Biology, 8,143-158.

ROGERS, D.M., OLSON, B.L. AND WILMORE, J., 1995, Scaling of the ${ }_{\mathrm{O}_{2} \text {-to-body-size }}$ relationship among children and adults, Journal of Applied Physiology, 79, 958-967.

SCRIMSHAW, N.S., WATERLOW, J.C. AND SCHÜRCH, B. (Eds), 1996, Energy and Protein requirements, Proceedings of an IDECG workshop, International Dietary Energy Consultative Group, October 31 - November 4, 1994; European Journal of Clinical Nutrition, 50, Suppl. 1. http://www.unu.edu/unupress/food2/UID01E/uid01e00.htm\#Contents 
SPADANO, J. L., MUST, A., BANDINI, L.G., DALLAL, G.E. AND DIETZ, W.H., 2003, Energy cost of physical activities in 12-y-old girls: MET values and the influence of body weight, International Journal of Obesity, 27, 1528-1533.

SPADANO, J. L., BANDINI, L.G., MUST, A., DALLAL, G.E. AND DIETZ, W.H., 2005, Longitudinal changes in energy expenditure in girls from late childhood through midadolescence, American Journal Of Clinical Nutrition, 81, 1102-1109.

SPITZER H., HETTINGER, T. AND KAMINSKY G., 1982, Tafeln für den Energieumsatz bei körperlicher Arbeit, Beuth verlag, Berlin.

SYSTAT, 2004, Systat Software, Inc.501 Canal Blvd, Suite E Point Richmond, CA 948042028, USA.

TORUN, B., 1983, Inaccuracy of applying energy expenditure rates of adults to children (letter), American Journal of Clinical Nutrition, 813-814.

TORUN, B., 1989, Energy cost of various physical activities in healthy children. In: Schürch B, Scrimshaw NS (eds) Activity, energy expenditure and energy requirements of infants and children. International Dietary Energy Consultancy Group, Switzerland, 139-183.

TORUN, B. AND VITERI, F.E., 1981, Capacity of habitual Guatemalan diets to satisfy protein requirements of preschool children with adequate dietary energy intakes. Food Nutrition Bulletin, Suppl. 5, 210-228.

WANG, J. AND HIHARA E., 2003, Human body surface area: a theoretical approach, European Journal of Applied Physiology, 91, 425-428.

WEIR, J.B.d.V., 1949, New methods for calculating metabolic rate with special reference to protein metabolism. Journal of Physiology, 109, 1-9.

WORLD HEALTH ORGANIZATION, 1985, Energy and protein requirements: report of a joint FAO/WHO/UNU expert consultation. Geneva: WHO. 
Table 1: Overview of measurement situations

\begin{tabular}{|c|c|c|c|}
\hline Lessons \# & Group & & Description \\
\hline \multicolumn{4}{|c|}{ Primary School: } \\
\hline 1 & A & Language, assignment & $\begin{array}{l}\text { Seated Activity, students work } \\
\text { individually on worksheets }\end{array}$ \\
\hline 2 & $\mathrm{~A}$ & Writing task & Seated activity, pupils write story \\
\hline 3 & $\mathrm{~A}$ & Art & $\begin{array}{l}\text { Seated activity, cutting and pasting with } \\
\text { paper }\end{array}$ \\
\hline 4 & $\mathrm{~B}$ & drawing & Seated activity \\
\hline 5 & $\mathrm{~B}$ & calculus & $\begin{array}{l}\text { Seated activity. Teacher explains. Pupils } \\
\text { listen and follow material in book }\end{array}$ \\
\hline \multicolumn{4}{|c|}{ Junior vocational (technical) education } \\
\hline 6 & $\mathrm{C}$ & Physics/Science test & Seated activity, writing. \\
\hline 7 & $\mathrm{C}$ & $\begin{array}{l}\text { Physics/Science } \\
\text { practical }\end{array}$ & $\begin{array}{l}\text { Sitting and standing, walking through } \\
\text { classroom to get material and talk to } \\
\text { teacher and other pupils }\end{array}$ \\
\hline 8 & $\mathrm{C}^{*}$ & $\begin{array}{l}\text { Woodworking, } \\
\text { machining }\end{array}$ & $\begin{array}{l}\text { Standing at woodworking machine, light } \\
\text { manual work }\end{array}$ \\
\hline 9 & $\mathrm{C}^{*}$ & Woodworking, manual & $\begin{array}{l}\text { Standing and sitting at workbench, light } \\
\text { manual work }\end{array}$ \\
\hline 10 & $\mathrm{C}^{*}$ & Welding & $\begin{array}{l}\text { Standing and sitting at workbench, light } \\
\text { manual work }\end{array}$ \\
\hline 11 & $\mathrm{C}$ & Physical Education & Cooper test \\
\hline 12 & $\mathrm{C}$ & Physical Education & Volleyball, game explanation and play \\
\hline \multicolumn{4}{|c|}{ Retail school (vocational education) } \\
\hline 13 & $\mathrm{D}$ & $\begin{array}{l}\text { Shopwindow } \\
\text { decoration }\end{array}$ & Standing, walking, light manual work \\
\hline 14 & $\mathrm{E}$ & $\begin{array}{l}\text { Shopwindow } \\
\text { decoration }\end{array}$ & Standing, walking, light manual work \\
\hline 15 & $\mathrm{D}$ & Technical drawing & Sitting, light manual work \\
\hline 16 & $\mathrm{D}$ & Typing Lessons & Sitting light manual work \\
\hline 17 & $\mathrm{D}$ & Social Science & Sitting, Listening, Discussing \\
\hline 18 & $\mathrm{D}$ & Administration & Sitting, Listening, Discussing, writing \\
\hline 19 & $\mathrm{E}$ & Administration & Sitting, Listening, Discussing, writing \\
\hline 20 & $\mathrm{D}$ & Arts & $\begin{array}{l}\text { Sitting, Standing, working with paper } \\
\text { materials }\end{array}$ \\
\hline \multicolumn{4}{|c|}{ Senior vocational (technical) education } \\
\hline 21 & $\mathrm{E}$ & $\begin{array}{l}\text { Physics/Science } \\
\text { practical }\end{array}$ & $\begin{array}{l}\text { Sitting and standing, walking through } \\
\text { classroom to get material and talk to } \\
\text { teacher and other pupils }\end{array}$ \\
\hline 22 & $\mathrm{E}$ & ‘Concrete’ practical & $\begin{array}{l}\text { Sitting, standing, walking, working with } \\
\text { base materials for concrete production, } \\
\text { light manual work }\end{array}$ \\
\hline 23 & $\mathrm{E}$ & $\begin{array}{l}\text { Business } \\
\text { Administration }\end{array}$ & $\begin{array}{l}\text { Seated Activity, students work } \\
\text { individually on worksheets }\end{array}$ \\
\hline 24 & $\mathrm{E}$ & $\begin{array}{l}\text { Drawing, road and } \\
\text { water management }\end{array}$ & $\begin{array}{l}\text { Standing Activity, students work } \\
\text { individually on drawing tables }\end{array}$ \\
\hline 25 & $\mathrm{E}$ & 'Asphalt' practical & Mostly theoretical; Seated activity. \\
\hline
\end{tabular}


Table 2, Mean $( \pm \mathrm{SD})$ physical data and clothing parameters of participant groups used in determination of clothing insulation.

\begin{tabular}{l|llllll}
\hline Group & $A$ & $B$ & $C$ & $C^{*}$ & $D$ & $E$ \\
\hline $\mathrm{N}$ & 27 & 23 & 21 & 21 & 13 & 12 \\
\hline Mass (kg) & 36.0 & 38.3 & 50.9 & 50.9 & 58.4 & 72.8 \\
& \pm 5.9 & \pm 6.1 & \pm 11.1 & \pm 11.1 & \pm 8.2 & \pm 6.5 \\
Stature (cm) & 147 & 153 & 164 & 164 & 173 & 186 \\
& \pm 7 & \pm 6 & \pm 9 & \pm 9 & \pm 8 & \pm 5 \\
Body surface area & 1.23 & 1.29 & 1.53 & 1.53 & 1.69 & 1.96 \\
A $_{\mathrm{D}}\left(\mathrm{m}^{2}\right.$ ) & & & & & & \\
& \pm 0.11 & \pm 0.12 & \pm 0.18 & \pm 0.18 & \pm 0.12 & \pm 0.10 \\
Clothing weight (g) & 965 & 1036 & 1179 & 1938 & 1144 & 1607 \\
& \pm 193 & \pm 176 & \pm 214 & \pm 348 & \pm 192 & \pm 301 \\
Clothing weight $^{1}$ (g) & 1417 & 1448 & 1398 & 2314 & 1215 & 1478 \\
& \pm 262 & \pm 233 & \pm 269 & \pm 451 & \pm 170 & \pm 285 \\
BSA $_{\mathrm{O}}$ (\%) & 14.3 & 14.1 & 13.9 & 13.8 & 13.7 & 14.6 \\
& \pm 1.6 & \pm 1.1 & \pm 1.7 & \pm 0.4 & \pm 3.7 & \pm 3.9 \\
BSA $_{\mathrm{l}}$ (\%) & 36.0 & 36.2 & 42.2 & 2.1 & 41.3 & 33.0 \\
& \pm 7.2 & \pm 6.6 & \pm 13.8 & \pm 0.3 & \pm 15.9 & \pm 6.9 \\
$I_{\text {cl }}$ (clo) & 0.97 & 0.98 & 0.94 & 1.38 & 0.90 & 1.00 \\
& \pm 0.09 & \pm 0.06 & \pm 0.11 & \pm 0.13 & \pm 0.10 & \pm 0.12 \\
CV (=SD/mean, \%) & 9 & 6 & 12 & 9 & 11 & 12 \\
\hline
\end{tabular}

BSA0 = nude body surface area; BSA1=body surface area with single clothing layer; weight=weight of clothing without shoes; weight1=clothing weight scaled for body surface area; $\mathrm{CV}=$ coefficient of variation in clothing insulation within group.

A. $\quad$ Primary school, level 6 (UK equivalent: year level 5), age 9-10 year;

B. $\quad$ Primary school, level 7 (UK equivalent: year level 6), age 10-11 year;

C. Junior vocational (technical) education (junior high school) age 13-16;

C* Same as C, but including protective coveralls for clothing insulation determination

D. Junior vocational education, advanced level (junior high school) age 13-16;

E. Senior vocational (technical) education, advanced level (senior high school) age 1618. 
Table 3: Data for measurement of metabolic rate. Room type: $\mathrm{T}=$ theory, $\mathrm{P}=$ Practical, $\mathrm{C}=$ combined. Method=manner in which metabolic rate was determined. $A_{D}=$ body surface area; metabolic rate $*=$ metabolic rate corrected for weight of equipment carried; \#:SD is not present for diaferometer as whole group of 5 participants was measured connected together to the same analyser, giving a total oxygen uptake for the group that is then divided by 5 .

\begin{tabular}{|c|c|c|c|c|c|c|c|c|c|c|c|c|c|c|c|}
\hline & & Group & $\mathrm{n}$ & $\begin{array}{l}\text { Room } \\
\text { type }\end{array}$ & $\begin{array}{c}\text { Air } \\
\text { Temperature } \\
\left({ }^{\circ} \mathrm{C}\right)\end{array}$ & method & $\begin{array}{l}\text { Metabolic } \\
\text { Rate (W) }\end{array}$ & sd & $\begin{array}{l}\mathrm{A}_{\mathrm{D}} \\
\left(\mathrm{m}^{2}\right)\end{array}$ & $\begin{array}{l}\text { Weight } \\
\text { (kg) }\end{array}$ & \begin{tabular}{|c|} 
Metabolic \\
Rate \\
$\left(\mathrm{W} . \mathrm{kg}^{-1}\right)$
\end{tabular} & $\begin{array}{c}\text { Metabolic } \\
\text { Rate } \\
\left(\mathrm{W} \cdot \mathrm{m}^{-2}\right)\end{array}$ & sd & $\begin{array}{c}\text { Metabolic } \\
\text { Rate* } \\
\left(\mathrm{W} \cdot \mathrm{m}^{-2}\right)\end{array}$ & sd \\
\hline \multicolumn{16}{|c|}{ Primary school } \\
\hline 1 & Language, assignment & $\mathrm{A}$ & 5 & $\mathrm{~T}$ & 18.4 . & diaf & 63 & $\#$ & 1.22 & 34.1 & 1.86 & 52 & $\#$ & 52 & $\#$ \\
\hline 2 & Writing task & $\mathrm{A}$ & 5 & $\mathrm{~T}$ & 19.5 & diaf & 68 & $\#$ & 1.29 & 38.1 & 1.79 & 53 & $\#$ & 53 & $\#$ \\
\hline 3 & Art & $\mathrm{A}$ & 5 & $\mathrm{P}$ & 20.5 & diaf & 77 & $\#$ & 1.29 & 37.8 & 2.01 & 59 & $\#$ & 59 & \# \\
\hline 4 & Drawing & $\mathrm{B}$ & 5 & $\mathrm{~T}$ & 21.5 & diaf & 79 & $\#$ & 1.27 & 36.5 & 2.15 & 62 & $\#$ & 62 & $\#$ \\
\hline 5 & Calculus & $\mathrm{B}$ & 5 & $\mathrm{~T}$ & 22 & diaf & 84 & $\#$ & 1.30 & 37.6 & 2.22 & 64 & \# & 64 & \# \\
\hline \multicolumn{16}{|c|}{ Junior vocational (technical) education } \\
\hline 6 & Physics/Science test & $\mathrm{C}$ & 4 & $\mathrm{~T}$ & 22.8 & oxyl & 128 & 17 & 1.75 & 62.5 & 2.05 & 73 & 9 & 73 & 9 \\
\hline 7 & $\begin{array}{l}\text { Physics/Science } \\
\text { practical }\end{array}$ & $\mathrm{C}$ & 3 & $\mathrm{C}$ & 20.1 & oxyl & 122 & 20 & 1.77 & 62.2 & 1.96 & 69 & 10 & 69 & 10 \\
\hline 8 & $\begin{array}{l}\text { Woodworking, } \\
\text { machining }\end{array}$ & $\mathrm{C}^{*}$ & 5 & $\mathrm{P}$ & 19.8 & oxyl & 214 & 53 & 1.66 & 59.8 & 3.58 & 129 & 28 & 121 & 28 \\
\hline 9 & $\begin{array}{l}\text { Woodworking, } \\
\text { manual }\end{array}$ & $\mathrm{C}^{*}$ & 4 & $\mathrm{P}$ & 18.1 & oxyl & 159 & 40 & 1.58 & 56.2 & 2.83 & 102 & 21 & 96 & 21 \\
\hline 10 & Welding & $\mathrm{C}^{*}$ & 3 & $\mathrm{P}$ & 17 & oxyl & 150 & 34 & 1.56 & 56.7 & 2.64 & 98 & 19 & 91 & 19 \\
\hline 11 & $\begin{array}{l}\text { Physical education } \\
\text { Cooper test }\end{array}$ & $\mathrm{C}$ & 2 & $\mathrm{P}$ & 18 & HR & 242 & $\begin{array}{c}27 \\
9 \\
\end{array}$ & 1.53 & 50.0 & 4.84 & 158 & $\begin{array}{c}16 \\
1\end{array}$ & 158 & 161 \\
\hline 12 & $\begin{array}{l}\text { Physical education } \\
\text { volleyball game } \\
\text { training }\end{array}$ & $\mathrm{C}$ & 2 & $\mathrm{P}$ & 18 & HR & 334 & \begin{tabular}{c|}
15 \\
7
\end{tabular} & 1.67 & 60.7 & 5.50 & $200^{1)}$ & 91 & $200^{1)}$ & 91 \\
\hline \multicolumn{16}{|c|}{ Retail school (vocational education) } \\
\hline 13 & $\begin{array}{l}\text { Shopwindow } \\
\text { decoration }\end{array}$ & $\mathrm{D}$ & 2 & $\mathrm{P}$ & 20.8 & oxyl & 148 & 37 & 1.58 & 52.7 & 2.85 & 95 & 24 & 87 & 24 \\
\hline 14 & $\begin{array}{l}\text { Shopwindow } \\
\text { decoration }\end{array}$ & $\mathrm{E}$ & 2 & $\mathrm{P}$ & 20.9 & oxyl & 203 & 45 & 1.89 & 68.5 & 2.98 & 108 & 24 & 102 & 24 \\
\hline 15 & Technical drawing & $\mathrm{D}$ & 3 & $\mathrm{P}$ & 20.9 & oxyl & 131 & 25 & 1.72 & 61.0 & 2.17 & 77 & 15 & 77 & 15 \\
\hline 16 & Typing lesson & $\mathrm{D}$ & 1 & $\mathrm{C}$ & 20.4 & oxyl & 134 & 9 & 1.75 & 62.8 & 2.15 & 77 & 5 & 77 & 5 \\
\hline 17 & Social science & $\mathrm{D}$ & 3 & $\mathrm{~T}$ & 20.4 & oxyl & 112 & 12 & 1.76 & 62.5 & 1.80 & 64 & 7 & 64 & 7 \\
\hline
\end{tabular}




\begin{tabular}{|c|c|c|c|c|c|c|c|c|c|c|c|c|c|c|c|}
\hline 18 & Administration & $\mathrm{D}$ & 2 & $\mathrm{~T}$ & 22.9 & oxyl & 98 & 16 & 1.70 & 60.2 & 1.64 & 58 & 9 & 58 & 9 \\
\hline 19 & Administration & $E$ & 2 & $\mathrm{~T}$ & 20.4 & oxyl & 122 & 16 & 2.06 & 75.1 & 1.65 & 60 & 8 & 60 & 8 \\
\hline 20 & Arts & $\mathrm{D}$ & 2 & $\mathrm{P}$ & 23.8 & oxyl & 157 & 29 & 1.70 & 58.4 & 2.69 & 93 & 17 & 93 & 17 \\
\hline \multicolumn{16}{|c|}{ Senior vocational (technical) education } \\
\hline 21 & $\begin{array}{l}\text { Physics/Science } \\
\text { practical }\end{array}$ & $\mathrm{E}$ & 4 & $\mathrm{C}$ & 21 & oxyl & 147 & 26 & 1.96 & 72.9 & 2.02 & 75 & 14 & 75 & 14 \\
\hline 22 & 'Concrete' practical & $\mathrm{E}$ & 4 & $\mathrm{P}$ & 11.3 & oxyl & 208 & 67 & 1.95 & 72.4 & 2.91 & 108 & 34 & 102 & 34 \\
\hline 23 & $\begin{array}{l}\text { Business } \\
\text { administration }\end{array}$ & $E$ & 2 & $\mathrm{~T}$ & 22.3 & oxyl & 149 & 32 & 1.94 & 72.4 & 2.09 & 78 & 17 & 78 & 17 \\
\hline 24 & $\begin{array}{l}\text { Drawing, road and } \\
\text { water management }\end{array}$ & $\mathrm{E}$ & 4 & $\mathrm{C}$ & 21.7 & oxyl & 167 & 35 & 2.08 & 75.2 & 2.21 & 80 & 17 & 80 & 17 \\
\hline & 'Asphalt' practical & $\mathrm{E}$ & 4 & $\mathrm{P}$ & 19.3 & oxyl & 150 & 37 & 1.86 & 66.4 & 2.27 & 81 & 20 & 76 & 20 \\
\hline
\end{tabular}

${ }^{1)}$ skewed distribution: $\mathrm{M}>300 \mathrm{~W} \cdot \mathrm{m}^{-2}$ for $29 \%$ of time and $\mathrm{M}<80 \mathrm{~W} \cdot \mathrm{m}^{-2}$ for $65 \%$ of time. 